\title{
LACK OF GERMLINE MUTATION AT CODON 211 OF THE PRION PROTEIN GENE (PRNP) IN KOREAN NATIVE CATTLE - SHORT COMMUNICATION
}

\author{
Yong-Chan $\mathrm{KIM}^{1,2}$ and Byung-Hoon JEONG ${ }^{1,2^{*}}$ \\ ${ }^{1}$ Korea Zoonosis Research Institute, Chonbuk National University, Iksan, \\ Jeonbuk 570-390, Republic of Korea; ${ }^{2}$ Department of Bioactive Material Sciences, \\ Chonbuk National University, Jeonju, Republic of Korea
}

(Received 8 August 2016; accepted 2 November 2016)

\begin{abstract}
Bovine prion diseases are composed of two types of bovine spongiform encephalopathy (BSE), classical BSE and atypical BSE. Recent studies have identified one case of atypical BSE with an E211K mutation. E211K is homologous to the human E200K mutation, which is related to familial Creutzfeldt-Jakob disease (CJD), one of the familial forms of human prion diseases. To date, familial forms of prion diseases have not been reported in non-human animals. Because the familial forms of human prion diseases account for more than $10 \%$ of all human prion disease cases, the detection of the $\mathrm{E} 211 \mathrm{~K}$ mutation in healthy cattle is very important for verifying the role of this mutation as a familial form of BSE. To detect putative mutations related to familial BSE, specifically E $211 \mathrm{~K}$ in Korean native cattle (Hanwoo) and Korean dairy cattle (Holstein), we performed direct sequencing targeting codon 211 and the adjacent regions of the bovine prion protein (PRNP) gene in 384 Hanwoo and 152 Holstein cattle. We did not find the E211K mutation in any of the Korean cattle. Although we did not find the E211K mutation in Korean native cattle, E2 $11 \mathrm{~K}$ is a postulated mutation; therefore, further screening in other countries and larger samples is highly desirable.
\end{abstract}

Key words: Bovine, prion protein gene, codon 211, mutation

Transmissible spongiform encephalopathies (TSEs), also called prion diseases, are characterised by the accumulation of an abnormal infectious form of the prion protein in humans and animals (Prusiner, 1998). Human prion diseases can occur spontaneously, be inherited, or be acquired. The inherited forms of human prion diseases include familial Creutzfeldt-Jakob disease (CJD), Gerstmann-Sträussler-Scheinker disease (GSS), and fatal familial insomnia (FFI), which are caused by germline mutations in the prion protein gene (PRNP). To date, more than 30 mutations of $P R N P$ in humans have been observed in the open reading frame (ORF) of $P R N P$ (Jeong and Kim, 2014). Among them, muta-

*Corresponding author; E-mail: bhjeong@jbnu.ac.kr; Phone: 0082 (63) 900-4040, Fax: 0082 (63) 900-4012 
tion at codon 200 of $P R N P$ is the most common mutation in European populations with genetic prion diseases, and it is strongly associated with familial forms of human prion disease such as familial CJD (Kovacs et al., 2005).

The major form of bovine prion diseases is classical bovine spongiform encephalopathy (BSE). It has been assumed that classical BSE was caused by feed that was made from scrapie-affected sheep (Wilesmith et al., 1988). In contrast, very few cases of sporadic forms of BSE have been reported in comparison to classical BSE. Animals affected by sporadic BSE, also called atypical BSE, have been reported in several countries; however, their aetiology has not been fully explained so far (Guldimann et al., 2012; Orge et al., 2015).

Recent studies have indicated that one case of atypical BSE, a putative inherited form of BSE, is related to a PRNP ORF mutation. The mutation, located in codon 211 of bovine $P R N P$, is in a region homologous with codon 200 of human PRNP. Both codon 200 in humans and codon 211 in cattle, encode the same amino acid, Glu (E), and the mutated amino acids are identical (Lys, K). Atypical BSE in an animal with the E211K mutation was first reported in 2006, in the US. Nicholson et al. (2008) performed sequence analysis of both the 2006 US atypical animal and its 2-year-old offspring. Both of them were heterozygous for the E211K mutation. These results suggest that this allele, which is associated with the familial form of atypical BSE, can be heritable (Nicholson et al., 2008).

In this context, we investigated the presence of a point mutation at codon 211 of the PRNP gene in the genomic DNAs of 536 Korean native cattle. Blood samples were taken from 384 Hanwoo and 152 Holstein cattle in South Korea. Genomic DNA was extracted from $200 \mu$ of whole blood using QIAamp ${ }^{\circledR}$ DNA Blood Mini Kit (QIAGEN, Valencia, CA, USA). Polymerase chain reaction (PCR) was performed with a sense primer (5'-CACATAGGCAGTTGGATCCTGG-3') and an antisense primer (5'-GGTACTGGGTAATGCACATTTGCTC-3'). After purification using the QIAquick ${ }^{\circledR}$ Gel Extraction Kit (QIAGEN), the PCR products were directly sequenced with an ABI 3730 Capillary Electrophoresis Sequencer (Applied Biosystems, Foster City, CA, USA).

The E211K mutation of bovine PRNP was not found in 1072 chromosomes of Korean Hanwoo and Holstein cattle (Table 1).

Table 1

Genotype and allele frequencies at codon 211 of the prion protein gene in Korean Hanwoo and Holstein cattle

\begin{tabular}{lcccccc}
\hline \multirow{2}{*}{ Sample } & Total, $\mathrm{n}$ & \multicolumn{2}{c}{ Genotype frequency $(\%)$} & & \multicolumn{2}{c}{ Allele frequency (\%) } \\
\cline { 7 - 7 } \cline { 6 - 7 } & & Glu/Glu & Glu/Lys & & Glu & Lys \\
\hline Hanwoo & 384 & $384(100)$ & $0(0)$ & & $768(100)$ & $0(0)$ \\
Holstein & 152 & $152(100)$ & $0(0)$ & & $304(100)$ & $0(0)$ \\
Total & 536 & $536(100)$ & $0(0)$ & & $1072(100)$ & $0(0)$ \\
\hline
\end{tabular}


BSE is classified into two types, classical BSE and atypical BSE. The first identification of TSE in cattle was classical BSE. Classical BSE was probably caused mainly by widespread prion-contaminated meat and bone meal (MBM) (Bradley and Wilesmith, 1993). The clinical signs of BSE may include tremors, ataxia, aggressive behaviour, apprehension, oversensitivity to stimuli, $\mathrm{PrP}^{\mathrm{Sc}}$ aggregation, and spongiform vacuolation of the brain (Novakofski et al., 2005). There have been several polymorphism studies in the PRNP ORF (Zhang et al., 2004; Jeong et al., 2005), and unlike human CJD, no direct relationship between classical BSE and PRNP ORF polymorphisms has been identified. Animals affected by classical BSE show a significantly higher frequency of the $23 \mathrm{bp}$ del/del genotype in the putative promoter region of PRNP (Jeong et al., 2006). In addition, a 12-bp indel polymorphism within intron 1 of $P R N P$ has been related to classical BSE (Haase et al., 2007; Gurgul et al., 2012a). However, several studies have failed to find a correlation between 12-bp indel polymorphisms and classical BSE (Hresko et al., 2009; Vernerova et al., 2014). Furthermore, SNP 4136 and 13861 in the noncoding region of PRNP have been shown to confer susceptibility to classical BSE (Murdoch et al., 2010; Jeong et al., 2013).

Another form of BSE, atypical BSE, is composed of two types, H-type and L-type. L-type BSE is also called bovine amyloidotic spongiform encephalopathy (BASE). Cattle affected by H-type BSE possess a higher molecular mass of unglycosylated $\mathrm{PrP}^{\text {res }}$ compared to those affected by classical BSE (Biacabe et al., 2004). However, cattle affected by L-type BSE contain a lower molecular mass of unglycosylated $\mathrm{PrP}^{\mathrm{res}}$ than those affected by classical BSE (Casalone et al., 2004). Generally, animals affected by either form of atypical BSE are older than those affected by classical BSE. In a recent study of Polish cattle, all of the cattle affected by atypical BSE were homozygous for a 23-bp deletion at the transcription factor binding site of $P R N P$, and they showed higher prevalence of a 12-bp deletion allele (Gurgul et al., 2012b). Furthermore, PRNP gene haplotypes are associated with both forms of atypical BSE (Clawson et al., 2008).

Among animals affected by H-type BSE, a novel form of BSE with mutation $\mathrm{E} 211 \mathrm{~K}$ has recently attracted attention due to the existence of a familial form in non-human animals. The E211K mutation of bovine PRNP is homologous to the E200K mutation in human $P R N P$, which is associated with a familial form of CJD. Nicholson et al. (2008) reported that the $211 \mathrm{~K}$ allele, a mutated form of codon 211, could be heritable. In addition, the authors performed intracranial inoculation of 2006 US H-type BSE with the K211 allele to a calf with the K211 allele. The calf showed severe clinical signs of BSE in a bioassay after 9.8 months. That is a shorter incubation period than has been observed for average H-type atypical BSE (Balkema-Buschmann et al., 2011). In addition, immunoblot analysis showed distinct molecular features distinguished from typical H-type BSE (Greenlee et al., 2012). Although two types of atypical BSE, H-type and L-type, did not transmit to three lines of human prion transgenic mice (HuMM, HuMV, 
HuVV) (Wilson et al., 2012; Wilson et al., 2013), the transmissibility to humans of this novel type of H-type atypical BSE, which contains the E211K mutation, has not been assessed thus far.

Based on previous reports, we investigated the E211K mutation in 384 Hanwoo and 152 Holstein cattle by direct sequencing. However, we did not identify the $\mathrm{K}$ allele in Korean cattle. This result indicates that the germline mutation at codon 211 of the bovine PRNP gene was not found in Korean native cattle. There is little research that focuses on E211K (Heaton et al., 2008; Zhao et al., 2010), and only few cases have been reported so far. Hence, further screening of E211K mutation in other countries is highly desirable in the future. If the offspring of US cattle affected by atypical BSE in 2006 show the clinical signs of $\mathrm{BSE}$ and detection of $\mathrm{PrP}^{\mathrm{Sc}}$ in the brain, a familial form of BSE will be verified for the first time in bovines. In addition, like in a prior study on the A117V mutation of $P R N P$, which is associated with GSS, the use of knock-in transgenic mice may help to determine the existence of a familial form of BSE in cattle (Yang et al., 2009). Furthermore, bioassays using E211K-mutant atypical BSE brain homogenate in human PRNP transgenic mice can be used to assess the risk of transmission to humans.

\section{Acknowledgements}

This research was supported by the Basic Science Program through the National Research Foundation of Korea (NRF) funded by the Ministry of Education, Science and Technology (2015R1D1A1A010599). Mr. Y.-C. Kim was supported by the BK21 Plus Program in the Department of Bioactive Material Sciences.

\section{References}

Balkema-Buschmann, A., Ziegler, U., McIntyre, L., Keller, M., Hoffmann, C., Rogers, R., Hills, B. and Groschup, M. H. (2011): Experimental challenge of cattle with German atypical bovine spongiform encephalopathy (BSE) isolates. J. Toxicol. Environ. Health A 74, 103-109.

Biacabe, A. G., Laplanche, J. L., Ryder, S. and Baron, T. (2004): Distinct molecular phenotypes in bovine prion diseases. EMBO Rep. 5, 110-115.

Bradley, R. and Wilesmith, J. W. (1993): Epidemiology and control of bovine spongiform encephalopathy (BSE). Br. Med. Bull. 49, 932-959.

Casalone, C., Zanusso, G., Acutis, P., Ferrari, S., Capucci, L., Tagliavini, F., Monaco, S. and Caramelli, M. (2004): Identification of a second bovine amyloidotic spongiform encephalopathy: molecular similarities with sporadic Creutzfeldt-Jakob disease. Proc. Natl Acad. Sci. USA 101, 3065-3070.

Clawson, M. L., Richt, J. A., Baron, T., Biacabe, A. G., Czub, S., Heaton, M. P., Smith, T. P. and Laegreid, W. W. (2008): Association of a bovine prion gene haplotype with atypical BSE. PloS One 3, e1830.

Greenlee, J. J., Smith, J. D., West Greenlee, M. H. and Nicholson, E. M. (2012): Clinical and pathologic features of H-type bovine spongiform encephalopathy associated with E211K prion protein polymorphism. PloS One 7, e38678. 
Guldimann, C., Gsponer, M., Drogemuller, C., Oevermann, A. and Seuberlich, T. (2012): Atypical H-type bovine spongiform encephalopathy in a cow born after the reinforced feed ban on meat-and-bone meal in Europe. J. Clin. Microbiol. 50, 4171-4174.

Gurgul, A., Czarnik, U., Larska, M., Polak, M. P., Strychalski, J. and Slota, E. (2012a): Polymorphism of the prion protein gene (PRNP) in Polish cattle affected by classical bovine spongiform encephalopathy. Mol. Biol. Rep. 39, 5211-5217.

Gurgul, A., Polak, M. P., Larska, M. and Slota, E. (2012b): PRNP and SPRN genes polymorphism in atypical bovine spongiform encephalopathy cases diagnosed in Polish cattle. J. Appl. Genet. 53, 337-342.

Haase, B., Doherr, M. G., Seuberlich, T., Drogemuller, C., Dolf, G., Nicken, P., Schiebel, K., Ziegler, U., Groschup, M. H., Zurbriggen, A. and Leeb, T. (2007): PRNP promoter polymorphisms are associated with BSE susceptibility in Swiss and German cattle. BMC Genet. 8, 15.

Heaton, M. P., Keele, J. W., Harhay, G. P., Richt, J. A., Koohmaraie, M., Wheeler, T. L., Shackelford, S. D., Casas, E., King, D. A., Sonstegard, T. S., Van Tassell, C. P., Neibergs, H. L., Chase, C. C., Jr., Kalbfleisch, T. S., Smith, T. P., Clawson, M. L. and Laegreid, W. W. (2008): Prevalence of the prion protein gene E211K variant in U.S. cattle. BMC Vet. Res. 4, 25.

Hresko, S., Mojzis, M. and Tkacikova, L. (2009): Prion protein gene polymorphism in healthy and BSE-affected Slovak cattle. J. Appl. Genet. 50, 371-374.

Jeong, B. H. and Kim, Y. S. (2014): Genetic studies in human prion diseases. J. Korean Med. Sci. 29, 623-632.

Jeong, B. H., Jin, H. T., Carp, R. I. and Kim, Y. S. (2013): Bovine spongiform encephalopathy (BSE)-associated polymorphisms of the prion protein (PRNP) gene in Korean native cattle. Anim. Genet. 44, 356-357.

Jeong, B. H., Sohn, H. J., Lee, J. O., Kim, N. H., Kim, J. I., Lee, S. Y., Cho, I. S., Joo, Y. S., Carp, R. I. and Kim, Y. S. (2005): Polymorphisms of the prion protein gene (PRNP) in Hanwoo (Bos taurus coreanae) and Holstein cattle. Genes Genet. Syst. 80, 303-308.

Jeong, B. H., Sohn, H. J., Lee, J. O., Kim, N. H., Kim, J. I., Lee, S. Y., Cho, I. S., Joo, Y. S., Carp, R. I. and Kim, Y. S. (2006): Genotype distribution of the prion protein gene (PRNP) promoter polymorphisms in Korean cattle. Genome 49, 1539-1544.

Kovacs, G. G., Puopolo, M., Ladogana, A., Pocchiari, M., Budka, H., van Duijn, C., Collins, S. J., Boyd, A., Giulivi, A., Coulthart, M., Delasnerie-Laupretre, N., Brandel, J. P., Zerr, I., Kretzschmar, H. A., de Pedro-Cuesta, J., Calero-Lara, M., Glatzel, M., Aguzzi, A., Bishop, M., Knight, R., Belay, G., Will, R., Mitrova, E. and EUROCJD (2005): Genetic prion disease: the EUROCJD experience. Hum. Genet. 118, 166-174.

Murdoch, B. M., Clawson, M. L., Laegreid, W. W., Stothard, P., Settles, M., McKay, S., Prasad, A., Wang, Z., Moore, S. S. and Williams, J. L. (2010): A 2cM genome-wide scan of European Holstein cattle affected by classical BSE. BMC Genet. 11, 20.

Nicholson, E. M., Brunelle, B. W., Richt, J. A., Kehrli, M. E., Jr. and Greenlee, J. J. (2008): Identification of a heritable polymorphism in bovine PRNP associated with genetic transmissible spongiform encephalopathy: evidence of heritable BSE. PloS One 3, e2912.

Novakofski, J., Brewer, M. S., Mateus-Pinilla, N., Killefer, J. and McCusker, R. H. (2005): Prion biology relevant to bovine spongiform encephalopathy. J Anim. Sci. 83, 1455-1476.

Orge, L., Machado, C. G., Ramalho, L., Carvalho, R., Silva, J., Almeida, P., Tavares, P., Ochoa, C., Lima, C., Pinto, M. J. and Simas, J. P. (2015): Identification of H-type BSE in Portugal. Prion 9, 22-28.

Prusiner, S. B. (1998): Prions. Proc. Natl Acad. Sci. USA 95, 13363-13383.

Vernerova, K., Tothova, L., Mikova, A., Vodrazka, P., Simek, B., Hanusova, L. and Citek, J. (2014): BSE-associated polymorphisms in the prion protein gene: an investigation. Anim. Breed Genet. 131, 403-408. 
Wilesmith, J. W., Wells, G. A., Cranwell, M. P. and Ryan, J. B. (1988): Bovine spongiform encephalopathy: epidemiological studies. Vet. Rec. 123, 638-644.

Wilson, R., Plinston, C., Hunter, N., Casalone, C., Corona, C., Tagliavini, F., Suardi, S., Ruggerone, M., Moda, F., Graziano, S., Sbriccoli, M., Cardone, F., Pocchiari, M., Ingrosso, L., Baron, T., Richt, J., Andreoletti, O., Simmons, M., Lockey, R., Manson, J. C. and Barron, R. M. (2012): Chronic wasting disease and atypical forms of bovine spongiform encephalopathy and scrapie are not transmissible to mice expressing wild-type levels of human prion protein. J. Gen. Virol. 93, 1624-1629.

Wilson, R., Plinston, C., Hunter, N., Casalone, C., Corona, C., Tagliavini, F., Suardi, S., Ruggerone, M., Moda, F., Graziano, S., Sbriccoli, M., Cardone, F., Pocchiari, M., Ingrosso, L., Baron, T., Richt, J., Andreoletti, O., Simmons, M., Lockey, R., Manson, J. C. and Barron, R. M. (2013): Presence of subclinical infection in gene-targeted human prion protein transgenic mice exposed to atypical bovine spongiform encephalopathy. J. Gen. Virol. 94, 2819-2827.

Yang, W., Cook, J., Rassbach, B., Lemus, A., DeArmond, S. J. and Mastrianni, J. A. (2009): A new transgenic mouse model of Gerstmann-Straussler-Scheinker syndrome caused by the A117V mutation of PRNP. J. Neurosci. 29, 10072-10080.

Zhang, L., Li, N., Fan, B., Fang, M. and Xu, W. (2004): PRNP polymorphisms in Chinese ovine, caprine and bovine breeds. Anim. Genet. 35, 457-461.

Zhao, H., Wang, X. Y., Zou, W. and Zhang, Y. P. (2010): Prion protein gene (PRNP) polymorphisms in native Chinese cattle. Genome 53, 138-145. 